\title{
Trik Membangun Bisnis Bagi Pengusaha Pemula Serius
}

\section{Berliana Puspitasari}

\author{
Universitas Nahdlatul Ulama Sidoarjo \\ berliana@protonmail.com
}

Skenario pasar saat ini telah melalui banyak pergolakan dengan gangguan teknologi untuk mendukung kekuatan pemasaran yang cerdas, sampai batas tertentu. Lingkungan seperti itu sangat menggetarkan bagi para wirausahawan untuk bertahan dan berkembang dengan tantangan yang menegangkan dan hasil yang memuaskan. Tidak ada akhir dari masalah keuangan, hukum, kepegawaian, pemasaran, dan pelanggan dari mana mereka dapat belajar ketika mereka bertemu dengan tugas mengembangkan usaha yang sukses dari ide pemikiran sendiri. Untuk orang-orang yang gagah, yang mau berjalan lebih jauh untuk merasakan kesuksesan yang sulit dipahami, berikut adalah beberapa tips untuk memulai dan membangun wirausaha pemula yang serius. 


\section{Meniru Pengusaha Terkemuka}

Untuk setiap bisnis, penting untuk meniru seorang pemimpin pasar, untuk menemukan kesuksesan dalam skenario yang tepat. Cari petunjuk dan saran dari mereka untuk memahami seluk-beluk pasar dengan lebih baik. Temukan mentor yang dapat memberi Anda saran tentang perekrutan, pengembangan produk, pemasaran, dan penggalangan dana namun jangan lupa untuk menerapkan merek pemasaran Anda. Sentuhan yang dipersonalisasi, dipasangkan dengan prosedur yang telah teruji membuat model bisnis yang lebih baik dari yang lainnya (Chakraborty, 2017). Memahami pendidikan untuk pengusaha dengan edupreneur (Purnomo, 2017).

\section{Cari Tahu Apa yang Diinginkan Pasar Anda dan Bangun untuk Mereka}

Kami tidak berlangganan teori membangunnya sehingga mereka konsumen akan datang. Kami ingin tahu apa yang mereka konsumen inginkan, dan itulah yang akan kami bangun (Basu, 2018).

\section{Percaya kepada Kekuatan Tuhan}

Tips mengelola institusi pendidikan wirausaha adalah niat mendidik dan berjuang karena Allah ta'ala. Niscaya rintangan sebesar apapun akan 
terasa ringan dihadapan kita (Yuniarti et al., 2017). Pemimpin wirausaha harus seperti Ilmu Nahwu dalam Bahasa Arab yaitu harus bisa Marfu' (dhummah) dan Manshub (fathah), jangan seperti Majrur dan Majzum. Marfu' yang berarti memeluk atau merangkul, sedangkan Manshub yang berarti terbuka tanpa ada yang ditutupi (Maula et al., 2017; Qori'ah et al., 2017). Wirausaha senantiasa harus selalu berpegang teguh pada sifat yang dimiliki oleh Rasul SAW yaitu jujur, amanah, fathana, siddiq selain itu juga harus bermodal ikhas, karena Allah ingin agamanya itu di amalkan (Munjidah, et al., 2017).

\section{Ambil Kembali Ruang Kepala Anda Terlebih Dahulu}

Sampai Anda mempelajari pemicu Anda dan dapat menenangkan dan menenangkan diri sendiri, Anda tidak akan membawa diri Anda yang terbaik (Meis, 2017).

\section{Gunakan Umpan Balik dari Pelanggan Anda untuk Mengubah dan Meningkatkan}

Tidak ada yang pernah benar-benar sempurna. Anda harus memutuskan bahwa inilah yang akan kami mulai, dan kemudian men-tweak berdasarkan umpan balik. Anda tidak ingin menunggu sampai Anda sempurna karena orang lain 
meluncurkan. Anda ingin meluncurkan, dan Anda mendapatkan umpan balik awal, dan Anda berubah dan Anda men-tweak (Basu, 2018).

\section{Kembangkan Kesabaran Anda}

Pada umumnya manusia bukan tipe orang yang sabar. Jadi ini membuat kami orang terbaik di dunia yang menyarankan Anda untuk bersabar. Kami sering memperhatikan konsekuensi negatif dari kurangnya kesabaran. Itu sama benarnya secara pribadi, seperti dalam bisnis. Dalam lokakarya dan ceramah kami, kami sering menjelaskan kepada pengusaha bahwa pengembangan bisnis membawa hasil yang tertunda. Ini berarti bahwa energi dan uang yang akan Anda investasikan dalam pemasaran Anda tidak akan membawa apa-apa dalam jangka pendek. Jadi kesabaran adalah kunci kesuksesan ketika memulai bisnis. Anda harus menerima sejak awal bahwa Anda harus memberikan banyak waktu untuk proyek bisnis Anda dan sejumlah besar energi. Akan ada periode mati yang lama sebelum semuanya benar-benar lepas landas. Sangat penting untuk mengetahui periode latensi ini, sehingga Anda dapat menghindari terus-menerus mempertanyakan diri sendiri dan membuang-buang energi Anda. Anda hanya harus menerimanya, menyingsingkan lengan baju Anda dan melanjutkan pekerjaan (L’Écuyer, 2016). Bijaksana dan pantang menyerah 
dalam belajar dan berwirausaha adalah kunci kesuksesan hidup dan wirausaha (Nahdiyah et al., 2017).

\section{Akui Situasi Anda}

Dunia dan masyarakat membutuhkan kewirausahaan (Setyawati, Purnomo, Irawan, Tamyiz, \& Sutiksno, 2018). Lakukan penilaian yang benar-benar objektif tentang ke mana Anda pergi dan apa yang menghalanginya (Meis, 2017).

\section{Bicaralah dengan Pesaing Anda}

Meskipun tampaknya berlawanan dengan keinginan untuk bergaul dengan musuh, itu merupakan langkah penting!. Ketika kami muda, orang tua kami sering mengajak kami makan es krim. Kami tahu, kami sangat manja!. Mereka berteman dengan pemilik toko es krim di sudut. Suatu hari yang panas, kami melihat kompetitornya datang untuk membeli saham darinya. Dia sudah kehabisan dan ingin terus melakukan penjualan. Anda tahu? Pemiliknya menjual kepadanya es krim.

Dari sudut pandang berpengetahuan dari seorang anak berusia enam tahun, kami terkejut. Kami memakan kerucut kami dan mencoba memahami apa yang baru saja terjadi. Anda harus menyadari bahwa pesaing Anda bukanlah musuh Anda. Sebaliknya, mereka harus menjadi teman baik Anda. 
Mereka bekerja di industri Anda dan mereka menginginkan hal yang sama Anda lakukan, untuk menyenangkan klien yang sama dengan Anda. Sama seperti Anda, pesaing Anda telah mengembangkan pengetahuan dan filosofi tentang industri ini. Pengetahuan ini adalah salah satu sumber daya terpenting untuk memulai bisnis. Jadi mengapa tidak membahas subjek secara bebas. Menjaga hubungan bisnis yang sehat dengan para pesaing memungkinkan Anda tidak hanya untuk secara teratur menjaga denyut nadi industri; itu juga bisa mengarah pada kemitraan. Inilah yang disebut coopetition. Baik melalui usaha patungan, aliansi pemasaran atau investasi dalam penelitian dan pengembangan, koopetisi menguntungkan kedua belah pihak. Jadi, jangan merampas segala yang dapat dilakukan oleh perusahaan Anda dari pesaing Anda (L'Écuyer, 2016).

\section{Tempatkan Keyakinan Anda pada Mentor yang Tepercaya}

Itu bisa berupa anggota keluarga, mantan bos atau kolega atau bahkan sumber atau blog online tepercaya. Seorang mentor adalah papan suara yang sangat berharga - seseorang yang pernah berada di tempat Anda; seseorang dengan siapa Anda dapat melakukan check-in reguler dan tidak menghakimi. Data $61.9 \%$ responden dalam survei kami tidak 
memiliki mentor - namun mereka yang mengatakan bahwa mereka menemukan mentor memiliki dampak positif yang signifikan terhadap bisnis mereka. "Mentor kami mendorong kami melampaui ketakutan terbesar kami," kata seorang pengusaha perempuan yang ikut serta dalam survei kami. "Ini bukan seseorang yang akan mengambil alih", setuju Mariam Jakoet Harris dari Cooked Inc. "Itu adalah seseorang yang akan mengasuh dan membantu Anda." (Santam, 2018). Pendidikan wirausaha bertujuan menyampaikan ilmu dan mentransformasi orang lain menjadi pengusaha yang lebih baik (Fidiana, et al., 2017).

\section{Pengusaha yang Sehat}

Ini adalah tip yang setiap orang harus menganggap serius setiap saat, tetapi ketika Anda mencoba untuk menemukan kembali diri Anda sebagai wirausahawan, Anda tidak ingin melupakan apa yang paling penting, dan itu adalah kesehatan diri Anda dan keluarga Anda. Jika Anda pernah menghadapi penyakit serius atau berkepanjangan, Anda tahu bahwa Anda tidak ada artinya jika Anda tidak memiliki kesehatan, jadi pastikan Anda makan sehat, berolahraga secara teratur, dan cukup tidur. Jika Anda merasa sehat, Anda akan memiliki kekuatan dan energi untuk mencapai apa pun yang Anda tentukan, dan karenanya tetap sehat harus 
menjadi prioritas bagi setiap wirausahawan (Zarpentine, 2016).

\section{References}

Basu, T. (2018). Top 20 Tips for Building a Business from Successful Entrepreneurs. Retrieved May 16, 2019, from https://www.thinkific.com/blog/tips-buildinga-business-successful-entrepreneurs/

Chakraborty, R. (2017). \#7 Best Tips for First-time Entrepreneurs. Retrieved May 31, 2019, from https://www.entrepreneur.com/article/298901

Fidiana, W., Istiana, Z., Rosyidah, E., Purnomo, A. (2017). MINU Waru 2 Insan Berkilau Cahaya Manfaat. In Wirausaha Pendidikan Indonesia (Jilid 4). Sidoarjo: Unusida Press.

L'Écuyer, J.-P. (2016). Ten Tips to Becoming a Better Entrepreneur. Retrieved May 24, 2019, from

https://www.futurpreneur.ca/en/2016/ten-tipsto-becoming-a-better-entrepreneur/

Maula, I., Mufidah, F.I., Rosyidah, E., \& Purnomo, A. (2017). SD Antawirya Islamic Javanese School Mother is Culture. In Wirausaha Pendidikan Indonesia (Jilid 1). Sidoarjo: Unusida Press. 
Meis, C. (2017). 7 Tips for the Struggling

Entrepreneur. Retrieved June 6, 2019, from https://www.success.com/7-tips-for-thestruggling-entrepreneur/

Munjidah, A, Zannah, I.P.N., Purnomo, A., Rosyidah, E. (2017). MI Thoriqussalam Berpegang Kepada Rosul. In Wirausaha Pendidikan Indonesia (Jilid 4). Sidoarjo: Unusida Press.

Nahdiyah, K., Amrina, S., Purnomo, A., \& Rosyidah, E. (2017). SD Taman Pendidikan Islam Porong Iman Kuat Bekal di Akhirat. In Wirausaha Pendidikan Indonesia (Jilid 2). Sidoarjo: Unusida Press.

Purnomo, A. (2017). Pengertian Edupreneur. https://doi.org/10.31227/osf.io/8fnu6

Qori'ah, S., Sholikhah, S.A., Purnomo, A., \& Rosyidah, E. (2017). MI Progresif Bumi Sholawat dengan Kebenaran Semua Pasti Ada Jalan. In Wirausaha Pendidikan Indonesia (Jilid 3). Sidoarjo: Unusida Press.

Santam. (2018). 10 tips for becoming a successful entrepreneur. Retrieved June 6, 2019, from https://www.santam.co.za/blog/businessadvice/10-tips-for-becoming-a-successfulentrepreneur/ 
Setyawati, I., Purnomo, A., Irawan, D. E., Tamyiz, M., \& Sutiksno, D. U. (2018). A Visual Trend of Literature on Ecopreneurship Research Overviewed within The Last two Decades. Journal of Entrepreneurship Education, 21(4), 1-7. Retrieved from

https://www.abacademies.org/articles/avisual-trend-of-literature-on-ecopreneurshipresearch-overviewed-within-the-last-twodecades-7468.html

Sholichah, S.A., Istiqomah, A., Rosyidah, E., \& Purnomo, A. (2017). MI Darun Najah Berfikir Berkarya Berdzikir. In Wirausaha Pendidikan Indonesia (Jilid 3). Sidoarjo: Unusida Press.

Yuniarti, D., Kautsari, M.F., Sholichah, F., Purnomo, A., \& Rosyidah, E. (2017). SMP SMA Al-Amin Ponpes Bahrul Hidayah Serahkan pada Allah Ta'ala. In Wirausaha Pendidikan Indonesia (Jilid 1). Sidoarjo: Unusida Press.

Zarpentine, B. (2016). 10 Great Tips on How to Reinvent Yourself as an Entrepreneur. Retrieved June 4, 2019, from https://blog.cake.hr/how-to-reinvent-yourselfas-an-entrepreneur/ 